Article

\title{
Interactions between Vitamin D Status, Calcium Intake and Parathyroid Hormone Concentrations in Healthy White-Skinned Pregnant Women at Northern Latitude
}

\author{
Andrea Hemmingway ${ }^{1,2}$, Karen M. O'Callaghan ${ }^{1,2}$, Áine Hennessy ${ }^{1,2}$, George L. J. Hull ${ }^{1}$, \\ Kevin D. Cashman 1,3 (ID) and Mairead E. Kiely 1,2,*(D) \\ 1 Cork Centre for Vitamin D and Nutrition Research, School of Food and Nutritional Sciences, \\ University College Cork, T12 Y337 Cork, Ireland; andrea.hemmingway@ucc.ie (A.H.); \\ karenocall@gmail.com (K.M.O.); a.hennessy@ucc.ie (Á.H.); george.hull@ucc.ie (G.L.J.H.); \\ k.cashman@ucc.ie (K.D.C.) \\ 2 The Irish Centre for Fetal and Neonatal Translational Research (INFANT), University College Cork, \\ T12 Y337 Cork, Ireland \\ 3 Department of Medicine, University College Cork, T12 Y337 Cork, Ireland \\ * Correspondence: m.kiely@ucc.ie; Tel.: +35-32-1490-3394
}

Received: 18 June 2018; Accepted: 11 July 2018; Published: 17 July 2018

\begin{abstract}
Adverse effects of low vitamin D status and calcium intakes in pregnancy may be mediated through functional effects on the calcium metabolic system. Little explored in pregnancy, we aimed to examine the relative importance of serum 25-hydroxyvitamin D $(25(\mathrm{OH}) \mathrm{D})$ and calcium intake on parathyroid hormone (PTH) concentrations in healthy white-skinned pregnant women. This cross-sectional analysis included 142 participants (14 \pm 2 weeks' gestation) at baseline of a vitamin D intervention trial at $51.9^{\circ} \mathrm{N}$. Serum $25(\mathrm{OH}) \mathrm{D}, \mathrm{PTH}$, and albumin-corrected calcium were quantified biochemically. Total vitamin $\mathrm{D}$ and calcium intakes (diet and supplements) were estimated using a validated food frequency questionnaire. The mean \pm SD vitamin $\mathrm{D}$ intake was $10.7 \pm 5.2 \mu \mathrm{g} /$ day. With a mean $\pm \mathrm{SD}$ serum $25(\mathrm{OH}) \mathrm{D}$ of $54.9 \pm 22.6 \mathrm{nmol} / \mathrm{L}, 44 \%$ of women were $<50 \mathrm{nmol} / \mathrm{L}$ and $13 \%<30 \mathrm{nmol} / \mathrm{L}$. Calcium intakes (mean $\pm \mathrm{SD}$ ) were $1182 \pm 488 \mathrm{mg} /$ day and $23 \%$ of participants consumed $<800 \mathrm{mg} /$ day. The mean $\pm \mathrm{SD}$ serum albumin-adjusted calcium was $2.2 \pm 0.1 \mathrm{mmol} / \mathrm{L}$ and geometric mean $(95 \% \mathrm{CI}) \mathrm{PTH}$ was $9.2(8.4,10.2) \mathrm{pg} / \mathrm{mL}$. PTH was inversely correlated with serum $25(\mathrm{OH}) \mathrm{D}(r=-0.311, p<0.001)$, but not with calcium intake or serum calcium $(r=-0.087$ and 0.057 , respectively, both $p>0.05)$. Analysis of variance showed that while serum $25(\mathrm{OH}) \mathrm{D}$ (dichotomised at $50 \mathrm{nmol} / \mathrm{L}$ ) had a significant effect on PTH $(p=0.025)$, calcium intake $(<800,800-1000, \geq 1000 \mathrm{mg} /$ day) had no effect $(p=0.822)$. There was no $25(\mathrm{OH}) \mathrm{D}$-calcium intake interaction effect on PTH $(p=0.941)$. In this group of white-skinned women with largely sufficient calcium intakes, serum $25(\mathrm{OH}) \mathrm{D}$ was important for maintaining normal PTH concentration.
\end{abstract}

Keywords: vitamin D; 25-hydroxyvitamin D; calcium; parathyroid hormone; pregnancy

\section{Introduction}

Nutritional adequacy during pregnancy is required for normal fetal development, prevention of maternal malnutrition and to support healthy perinatal outcomes [1]. Despite widespread evidence of low vitamin D status among pregnant women and newborn infants [2-7], antenatal vitamin D supplementation is not mandated in many jurisdictions due to conflicted evidence for a beneficial effect from randomised controlled trials on perinatal outcomes [8,9]. However, the trials to date 
have been few in number and relatively small [8,9] and many studies have observed associations between low maternal serum 25-hydroxyvitamin D $(25(\mathrm{OH}) \mathrm{D})$ concentrations and adverse perinatal outcomes [10]. At a minimum, low vitamin D status in pregnant women should be avoided and current recommendations for vitamin $\mathrm{D}$ intakes and status for the general population have been extended to pregnancy [11-13]. Recent studies have demonstrated that maintenance of maternal $25(\mathrm{OH}) \mathrm{D}$ $\geq 50 \mathrm{nmol} / \mathrm{L}$ in late gestation would prevent umbilical cord $25(\mathrm{OH}) \mathrm{D}$ falling below $25-30 \mathrm{nmol} / \mathrm{L}$, a threshold indicative of an increased risk of nutritional rickets [14,15].

Calcium intakes vary 5-fold worldwide and cultural, social, and food availability factors all contribute to low calcium intakes, which are common [16,17]. In the context of pregnancy, low calcium intakes may increase the risk of hypertensive disorders, particularly preeclampsia [18]. Vitamin D and calcium metabolism undergo many adaptations during pregnancy [19]. For example, concentrations of parathyroid hormone (PTH) decrease [20], and although the inverse association between 25(OH)D and PTH remains, it is somewhat attenuated [21]. The active form of vitamin $\mathrm{D}_{3}, 1,25$-dihydroxycholecalciferol $\left(1,25(\mathrm{OH})_{2} \mathrm{D}_{3}\right)$, functions within the calcium metabolic system to maintain serum calcium levels under homeostatic control [11]. A sustained low 25(OH)D concentration, which limits production of $1,25(\mathrm{OH})_{2} \mathrm{D}_{3}$, ultimately leads to a slight decrease in serum calcium levels, triggering the secretion of $\mathrm{PTH}$ which stimulates bone resorption [22]. Thus, secondary hyperparathyroidism refers to elevation of $\mathrm{PTH}$ resulting from low 25(OH)D [23] and represents a functional vitamin D deficiency, encompassing a sub-group of those with low $25(\mathrm{OH}) \mathrm{D}$ concentrations.

Recently, we [24] and others [25] have explored the concept of functional vitamin D deficiency in pregnancy, where adverse effects of low $25(\mathrm{OH}) \mathrm{D}$ are mediated through a functional impact on the calcium metabolic system. Inadequacy of calcium intake may also increase PTH concentrations and impact perinatal outcomes in this manner. Little explored in pregnancy, we aimed to examine the relative importance of serum $25(\mathrm{OH}) \mathrm{D}$ and calcium intake on PTH concentrations among healthy white-skinned pregnant women.

\section{Materials and Methods}

\subsection{Study Design and Participants}

This cross-sectional analysis is of baseline data from a randomised controlled dietary intervention trial designed to identify the maternal vitamin $\mathrm{D}$ intake in pregnancy that would maintain serum $25(\mathrm{OH}) \mathrm{D}$ in late gestation at a concentration sufficient to keep umbilical cord 25(OH)D $\geq 25-30 \mathrm{nmol} / \mathrm{L}$ [14]. The study was a three-arm, parallel, dose-response, double-blind, placebo-controlled randomised trial of vitamin $\mathrm{D}_{3}$ supplementation. The power calculation was based on similar dose-response studies of vitamin $\mathrm{D}$ nutritional requirements designed by our research group, whereby 31 participants per arm is adequate to detect a $10 \mathrm{nmol} / \mathrm{L}$ difference in $25(\mathrm{OH}) \mathrm{D}$ concentrations and provide a $90 \%$ power to demonstrate a dose-response relation with slope 1.5 and alpha equal to 0.05 [26-29]. This study was conducted throughout the year because it was a pregnancy study, with three assessment points across gestation, unlike our previous trials in non-pregnant groups which were conducted during winter time. To enable a season-specific analysis and account for a potentially higher dropout rate in late gestation than we would usually see, the sample size was increased to 48 per arm (144 in total). From enrolment, at $\leq 18$ weeks' gestation, to late pregnancy, women were randomised to receive 10 or $20 \mu \mathrm{g} /$ day (400 or $800 \mathrm{IU}$ ) vitamin $\mathrm{D}_{3}$ or placebo.

Healthy pregnant women were recruited between November 2014 and April 2016, with Cork University Maternity Hospital, Cork, Ireland $\left(51.9^{\circ} \mathrm{N}\right)$ being the primary recruitment centre. Women were deemed eligible to participate if they were $\geq 18$ years of age, white-skinned, in general good health, not identified as having a high-risk pregnancy and with a gravidae of $\leq 18$ weeks' gestation. Exclusion criteria included current smoking, vegan diet, illness or medical condition, consumption of medications known to interfere with vitamin D metabolism and consumption of supplemental vitamin D (>10 $\mu \mathrm{g}$ /day) or calcium (>650 mg/d) prior to randomisation. 
Study visits took place at the Human Nutrition Studies Unit at the Cork Centre for vitamin D and Nutrition Research, University College Cork, Cork, Ireland, with the baseline visit at mean \pm SD of $14 \pm 2$ weeks' gestation. At baseline, trained researchers collected information on general health, lifestyle and socio-demographics. Habitual calcium and vitamin D intakes were estimated using a specifically designed and validated quantitative food frequency questionnaire [30]. The food frequency questionnaire was interviewer administered to improve precision and the validity coefficient for vitamin D intakes was 0.92 (95\% CI; 0.80-0.97) [30]. Height and weight were measured for calculation of BMI (Leicester height measure, CMS Weighing Equipment Ltd., London, UK; digital weighing scales, SECA Ltd., Birmingham, UK). Non-fasting blood samples were collected, processed to serum, and stored at $-80^{\circ} \mathrm{C}$ within $3 \mathrm{~h}$ of collection.

The study was conducted in accordance with the Declaration of Helsinki guidelines and ethical approval was obtained from the Clinical Research Ethics Committee of the Cork Teaching Hospitals (ECM4(o)04/02/14). The trial is registered at the United States National Institutes of Health Clinical Trials Registry (www.clinicaltrials.gov), ID: NCT02506439. Written informed consent was provided by all participants prior to study commencement.

\subsection{Biochemical Analysis}

\subsubsection{Serum $25(\mathrm{OH}) \mathrm{D}$}

The method used to measure 25(OH)D in our laboratory has been detailed previously [5]. Briefly, individually quantified $25(\mathrm{OH}) \mathrm{D}_{2}$ and $25(\mathrm{OH}) \mathrm{D}_{3}$ were summed to calculate total $25(\mathrm{OH}) \mathrm{D}$. Serum $25(\mathrm{OH}) \mathrm{D}_{2}$ and $25(\mathrm{OH}) \mathrm{D}_{3}$ concentrations were measured using liquid chromatography-tandem mass spectrometry (LC-MS/MS) on a Waters Acquity Ultra-Performance Liquid Chromatography system coupled to an Acquity Triple Quadrupole TQD mass spectrometer detector (Waters, Milford, MA, USA). Method validation used four levels of serum-based NIST (National Institute of Standards and Technology, Gaithersburg, MD, USA) certified quality assurance material (SRM 972) and quality control materials, purchased from Chromsystems (Munich, Germany), were assayed in parallel to all samples. NIST calibrators (SRM 2972) were used throughout the analysis. The limit of detection (LoD) for $25(\mathrm{OH}) \mathrm{D}_{3}$ and $25(\mathrm{OH}) \mathrm{D}_{2}$ was 0.31 and $0.44 \mathrm{nmol} / \mathrm{L}$, respectively. The limit of quantitation (LoQ) for $25(\mathrm{OH}) \mathrm{D}_{3}$ and $25(\mathrm{OH}) \mathrm{D}_{2}$ was 1.03 and $1.43 \mathrm{nmol} / \mathrm{L}$, respectively. The intra- and inter- assay coefficient of variations (CVs) for both metabolites were $<6 \%$ and $<5 \%$, respectively. The CDC vitamin D Standardization Certification program accredits the laboratory of the Cork Centre for vitamin D and Nutrition Research and the laboratory participates in the vitamin D External Quality Assessment Scheme (DEQAS) (Charring Cross Hospital, London, UK).

\subsubsection{Serum PTH}

Serum intact PTH was quantified using an enzyme-linked immunosorbent assay (ELISA) (MD Biosciences Inc., Oakdale, MN, USA) on the automated Dynex DS2 ${ }^{\circledR}$ ELISA processing platform (Dynex Technologies, Chantilly, VA, USA). Designed to measure biologically intact PTH 1-84, the assay utilizes two purified goat polyclonal antibodies. Mid-region and C-terminal PTH 39-84 is bound by a biotinylated antibody, while a horseradish peroxidase conjugated antibody binds N-terminal PTH 1-34 and is the detection antibody. The intra- and inter-assay CVs for intact PTH were $<3 \%$.

\subsubsection{Serum Calcium}

Colorimetric and immunoturbidimetric assays were used to measure serum calcium and albumin, respectively, on the Randox Monaco Automated Clinical Chemistry Analyser (Randox Laboratories Ltd., Co. Antrim, UK). Serum calcium was corrected for albumin as follows: corrected calcium $(\mathrm{mmol} / \mathrm{L})=$ measured total calcium $(\mathrm{mmol} / \mathrm{L})+0.02 \times(40-$ serum albumin $(\mathrm{g} / \mathrm{L}))$, where 40 represents the average albumin level in $\mathrm{g} / \mathrm{L}$ [31]. The mean inter-assay CV was $3 \%$. 


\subsection{Statistical Analysis}

Statistical analysis was performed using IBM SPSS ${ }^{\circledR}$ version 24.0 (IBM Corp., Armonk, NY, USA) software for Windows ${ }^{\mathrm{TM}}$ on 142 complete baseline datasets without imputation. Two participants did not have a blood sample at the baseline visit and were excluded from the current analysis. Participant characteristics are presented as mean \pm SD and percentage (frequency), as appropriate. PTH was natural log-transformed and log PTH was used in analysis; PTH is reported as geometric mean $(95 \% \mathrm{CI})$. BMI, maternal age, and gestational age were investigated as potential covariates in both continuous and categorical analysis of the calcium metabolic system. In continuous analysis, partial correlations indicated little influence of any covariate and thus zero-order Pearson's correlations are reported. For the categorical analysis, because there was no significant relationship between any potential covariate and PTH, ANOVA rather than analysis of covariance(ANCOVA) was used. The two-way ANOVA, with PTH as the dependent term, included categorical 25(OH)D, calcium intake and a $25(\mathrm{OH}) \mathrm{D}$-calcium intake interaction term. Serum $25(\mathrm{OH}) \mathrm{D}$ concentrations were dichotomised at $50 \mathrm{nmol} / \mathrm{L}$, the current individual target for $25(\mathrm{OH}) \mathrm{D}$ and calcium intakes were stratified at 800 and $1000 \mathrm{mg} /$ day, reflecting the estimated average requirement (EAR) and recommended dietary allowance (RDA) [11]. ANOVA was repeated using a 25(OH)D cut-off of $75 \mathrm{nmol} / \mathrm{L}$ [32].

\section{Results}

Participant characteristics in this cross-sectional analysis are shown in Table 1. The age of participants ranged from 21 to 41 years with a mean of $33 \pm 4$ years. Mean BMI was $25.8 \pm 4.3 \mathrm{~kg} / \mathrm{m}^{2}$; $49 \%$ of participants had a normal BMI, $37 \%$ were overweight, and $13 \%$ were obese. $78 \%$ of participants had their baseline visit in winter (defined as November to May), and visits took place at a mean gestational age of $14.3 \pm 1.8$ weeks.

Table 1. Sample characteristics of participants $(n=142)$

\begin{tabular}{cc}
\hline Characteristic & Value \\
\hline Age (years) & $33.4 \pm 3.8$ \\
BMI $\left(\mathrm{kg} / \mathrm{m}^{2}\right)$ & $25.8 \pm 4.3$ \\
Nulliparous & $32.4(46)$ \\
University Education & $70.4(100)$ \\
Winter season at baseline & $77.5(110)$ \\
visit ${ }^{1}$ & $14.3 \pm 1.8$ \\
Gestational Age at visit (weeks) & $68.3(97)$ \\
Vitamin D supplement user $^{\text {Calcium supplement user }}$ & $23.2(33)$ \\
Vitamin D intake $\left(\mu g /\right.$ day) $^{2}$ & $10.7 \pm 5.2$ \\
Calcium intake $(\mathrm{mg} / \mathrm{day})^{2}$ & $1182 \pm 488$ \\
Serum $25(\mathrm{OH}) \mathrm{D}(\mathrm{nmol} / \mathrm{L})^{\text {Serum PTH (pg/mL) }}$ & $54.9 \pm 22.6$ \\
${\text { Serum calcium }(\mathrm{mmol} / \mathrm{L})^{3}}^{3}$ & $9.2(8.4,10.2)$ \\
\hline
\end{tabular}

Data are presented as mean \pm SD or \% (frequency). PTH is presented as geometric mean ( $95 \%$ CI). BMI, body mass index; $25(\mathrm{OH}) \mathrm{D}, 25$-hydroxyvitamin D; PTH, parathyroid hormone. ${ }^{1}$ Winter: November through May. ${ }^{2}$ Includes intake from diet and supplements. ${ }^{3}$ Serum albumin-corrected calcium.

Mean vitamin D and calcium intakes were $10.7 \pm 5.2 \mu \mathrm{g} /$ day and $1182 \pm 488 \mathrm{mg} /$ day, respectively. Calcium intake was $<800 \mathrm{mg} /$ day in $23 \%$ (being $<600$ and $<500 \mathrm{mg}$ /day in $8 \%$ and $4 \%$, respectively) and $>1000 \mathrm{mg} /$ day in $63 \%$ of participants. Of those with a calcium intake $<800 \mathrm{mg} /$ day $41 \%$ had an intake in the range of $700-800 \mathrm{mg} /$ day. Mean $25(\mathrm{OH}) \mathrm{D}$ concentration was $54.9 \pm 22.6 \mathrm{nmol} / \mathrm{L}$; $44 \%$ of participants had a $25(\mathrm{OH}) \mathrm{D}<50 \mathrm{nmol} / \mathrm{L}, 13 \%$ were $<30 \mathrm{nmol} / \mathrm{L}$ and $23 \%$ were $\geq 75 \mathrm{nmol} / \mathrm{L}$. Mean serum albumin-adjusted calcium was $2.2 \pm 0.1 \mathrm{mmol} / \mathrm{L}$ and geometric mean $(95 \% \mathrm{CI}) \mathrm{PTH}$ was $9.2(8.4,10.2) \mathrm{pg} / \mathrm{mL}$. 
Correlations between components of the calcium metabolic system and vitamin D and calcium intakes are presented in Table 2. Serum 25(OH)D was correlated with vitamin D intake $(r=0.372$, $p<0.001)$ and inversely correlated $(r=-0.331, p<0.001)$ with PTH. Vitamin D and calcium intakes were weakly correlated $(r=0.194, p=0.021)$. PTH was not correlated with vitamin D or calcium intakes or with serum calcium $(r=-0.132,-0.087$ and 0.057 , respectively, all $p>0.05)$. Scatterplots of $\log$ PTH and $25(\mathrm{OH}) \mathrm{D}$ and $25(\mathrm{OH}) \mathrm{D}$ and vitamin D intake are available as supplementary Figures S1 and S2.

Table 2. Correlations between components of the calcium metabolic system, vitamin $\mathrm{D}$, and calcium intakes $(n=142)$.

\begin{tabular}{|c|c|c|c|c|c|}
\hline & & $25(\mathrm{OH}) \mathrm{D}$ & Serum Calcium $^{1}$ & Vitamin D Intake $^{2}$ & Calcium Intake $^{2}$ \\
\hline PTH & $\begin{array}{c}r \\
(n-\mathrm{v} a l u e)\end{array}$ & $\begin{array}{c}-0.311 \\
(<0.001)\end{array}$ & $\begin{array}{r}0.057 \\
(0.499)\end{array}$ & -0.132 & -0.087 \\
\hline 25(OH)D & $\begin{array}{c}r \\
(p \text {-value) }\end{array}$ & & $\begin{array}{r}-0.092 \\
(0.276)\end{array}$ & $\begin{array}{c}0.372 \\
(<0.001)\end{array}$ & $\begin{array}{c}0.064 \\
(0.448)\end{array}$ \\
\hline $\begin{array}{l}\text { Serum } \\
\text { calcium } 1\end{array}$ & $\begin{array}{c}r \\
\text { (p-value) }\end{array}$ & & & $\begin{array}{c}0.058 \\
(0.493)\end{array}$ & $\begin{array}{c}0.064 \\
(0.450)\end{array}$ \\
\hline $\begin{array}{l}\text { Vitamin D } \\
\text { intake }^{2}\end{array}$ & $\begin{array}{c}r \\
\text { (p-value) }\end{array}$ & & & & $\begin{array}{c}0.194 \\
(0.021)\end{array}$ \\
\hline
\end{tabular}

Data are presented as zero-order Pearson's correlations $(r)$ and $p$-values. 25(OH)D, 25 hydroxyvitamin-D;

PTH, parathyroid hormone. ${ }^{1}$ Serum albumin-corrected calcium. ${ }^{2}$ Includes intake from diet and supplements.

The results of an ANOVA to investigate the relative importance of serum 25(OH)D concentration and calcium intake to PTH concentration are graphically depicted in Figure 1. PTH differed significantly with serum $25(\mathrm{OH}) \mathrm{D}$ strata $(p=0.025)$ but not calcium intake strata $(p=0.822)$. When 25(OH)D was $<50 \mathrm{nmol} / \mathrm{L}$, geometric mean PTH was $10.9(7.8,15.5), 11.3(8.6,14.8)$ and $10.8(8.9$, 13.0) $\mathrm{pg} / \mathrm{mL}$ with calcium intakes $<800,800-1000$ and $\geq 1000 \mathrm{mg} /$ day, respectively. Concentrations of PTH were lower in each calcium intake group when $25(\mathrm{OH}) \mathrm{D}$ was $\geq 50 \mathrm{nmol} / \mathrm{L}(8.6(6.5,11.5)$, $8.7(6.4,11.8)$ and $7.8(6.6,9.4) \mathrm{pg} / \mathrm{mL}$, respectively). There was no evidence of an interaction between $25(\mathrm{OH}) \mathrm{D}$ and calcium intake on PTH concentrations $(p=0.941)$. Similar results were obtained when $75 \mathrm{nmol} / \mathrm{L}$ was used as a $25(\mathrm{OH}) \mathrm{D}$ cut-off (data not shown). PTH concentration was lower when $25(\mathrm{OH}) \mathrm{D} \geq 75 \mathrm{nmol} / \mathrm{L}(p=0.039)$ while PTH did not differ by calcium intake strata $(p=0.849)$ and there was no evidence of a nutrient-nutrient interaction on PTH concentrations ( $p=0.947)$.

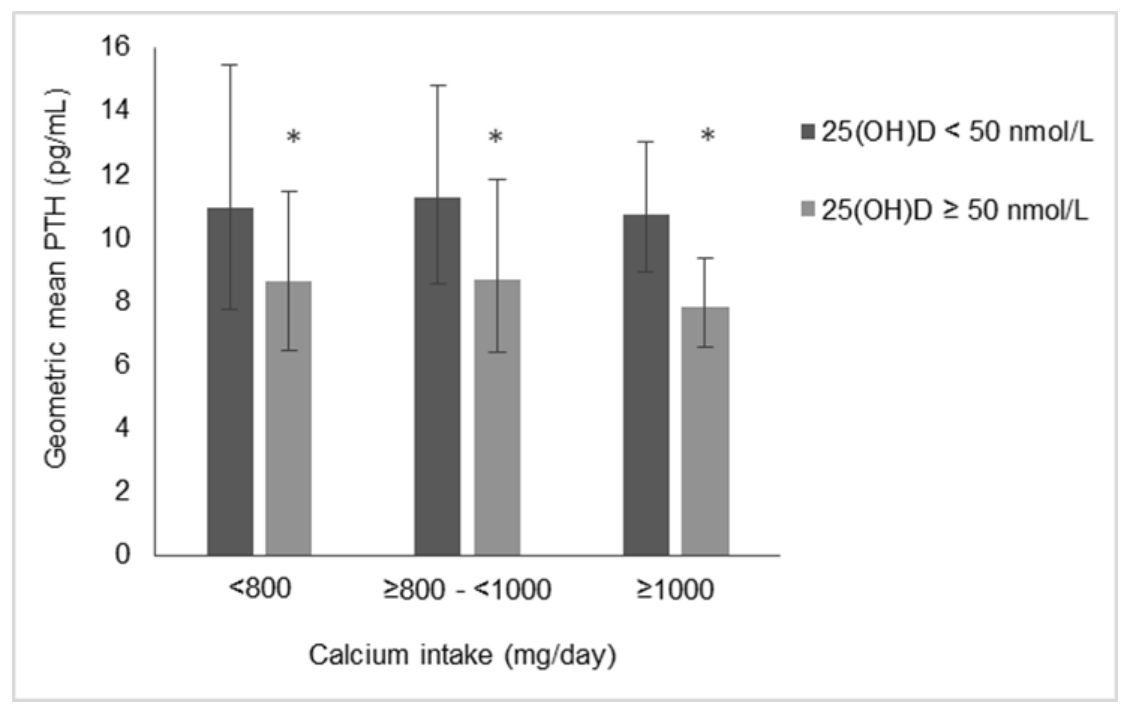

Figure 1. PTH concentrations in 142 pregnant women stratified by serum $25(\mathrm{OH}) \mathrm{D}$ and calcium intake. PTH values are geometric mean $(95 \% \mathrm{CI})$. *ANOVA indicated PTH differed significantly $(p<0.05)$ when $25(\mathrm{OH}) \mathrm{D} \geq 50 \mathrm{nmol} / \mathrm{L}$ compared to $<50 \mathrm{nmol} / \mathrm{L}$. 


\section{Discussion}

This study among white-skinned pregnant women at Northern latitude has demonstrated that serum 25(OH)D and not calcium intake, influences PTH concentrations. Thus, in this setting, with low vitamin D availability and relatively high calcium intakes, PTH differed with vitamin D status, with no evidence of an interaction between vitamin D and calcium on PTH concentrations. Our data were generated prospectively, using gold standard $25(\mathrm{OH}) \mathrm{D}$ analysis, in conjunction with a validated dietary assessment of vitamin D and calcium and was comprehensive in terms of serum calcium and PTH analysis and subject characterisation.

Our main analysis dichotomised 25(OH)D at $50 \mathrm{nmol} / \mathrm{L}$, reflective of the current $25(\mathrm{OH}) \mathrm{D}$ sufficiency threshold, as per the Institute of Medicine [11]. However, alternative vitamin D thresholds have been suggested [32] and we previously reported a protective effect of $25(\mathrm{OH}) \mathrm{D} \geq 75 \mathrm{nmol} / \mathrm{L}$ against combined preeclampsia and small-for-gestational-age [5]. Repetition of analysis using this cut-off gave similar results. While a $25(\mathrm{OH}) \mathrm{D}$ concentration $<30 \mathrm{nmol} / \mathrm{L}$ reflects an increased risk of adverse bone consequences [11], only $13 \%$ of this sample were $<30 \mathrm{nmol} / \mathrm{L}$, and thus, a robust analysis stratified by calcium intake was not possible due to small cell sizes.

Vitamin D intakes were higher in this study than in a group of nationally representative Irish women [33], likely as a result of greater supplement use and reflective of increased nutritional awareness during pregnancy. Similarly, the mean calcium intake in this group was $>1000 \mathrm{mg} /$ day, a higher intake than adult women in the general Irish population [34]. However, inadequate calcium intakes are common worldwide; an estimated 3.5 billion people are at risk and this is particularly frequent in low resource settings [35,36]. We defined a low calcium intake as below the EAR of $800 \mathrm{mg} /$ day [11]. The EAR is set on the basis of meeting the calcium intake needs of $50 \%$ of the population and a calcium intake slightly below the EAR may be adequate on an individual basis. Intakes of calcium were $700-800 \mathrm{mg} /$ day in $41 \%$ of those with low calcium intake. Investigation of the effects of very low calcium intakes on PTH is of interest but was not possible in this analysis where only $8 \%$ and $4 \%$ of participants had intakes $<600$ and $<500 \mathrm{mg} /$ day, respectively.

Pregnancy specific studies of the vitamin D-calcium metabolic system are warranted given the substantial metabolic alterations that occur in this system in pregnancy [19]. These include increases in vitamin $\mathrm{D}$ binding protein and $1,25(\mathrm{OH})_{2} \mathrm{D}$, a decrease in PTH and little/no change in serum calcium and 25(OH)D [37], which collectively allow maternal physiological adaptation to pregnancy. To the best of our knowledge we present the first report of the effects of $25(\mathrm{OH}) \mathrm{D}$ concentrations and calcium intakes on PTH in pregnancy. Studies to date in non-pregnant adults are conflicting. In a case-control analysis in a Nordic sample, Jorde et al., found no difference in $25(\mathrm{OH}) \mathrm{D}$ concentrations between those with normal or elevated PTH, while both calcium intakes and serum calcium were significantly lower when PTH was elevated [38]. Irrespective of PTH status, calcium intakes were low, at a mean of $<600 \mathrm{mg} /$ day. In a larger study in Iceland, with mean calcium intakes $>1200 \mathrm{mg} /$ day, maintenance of 25(OH)D concentrations $>\sim 45 \mathrm{nmol} / \mathrm{L}$ protected against elevations in serum PTH [39]. In contrast, while a calcium intake $>1200 \mathrm{mg} / \mathrm{d}$ mitigated against the effect of very low $25(\mathrm{OH}) \mathrm{D}(<25 \mathrm{nmol} / \mathrm{L})$ on PTH, it was not sufficient to maintain PTH. A population-based analysis in Korea, with low habitual calcium intakes, reported that both $25(\mathrm{OH}) \mathrm{D}$ and calcium were important to circulating PTH [40]. However, there was a lack of consistency in PTH concentrations across both 25(OH)D and calcium groups.

Investigating the potential vitamin D-sparing effect of habitual high calcium intakes, Cashman et al., carried out a 15-week, winter-based vitamin D intervention trial [41] in older adults in the current setting. At baseline, PTH was significantly higher among participants with moderate-low calcium intakes (<700 mg/day) compared with high calcium intakes ( $>1000 \mathrm{mg} /$ day). After the intervention period, there was a significant effect of vitamin D treatment on PTH concentration, with no effect of habitual calcium intake and no calcium-vitamin D interaction effect on PTH. The habitual calcium intake and the participant population appear to be critical factors. 
Evidence of interplay between the calcium metabolic system and perinatal health is accumulating, and interactions within the calcium metabolic system are of interest in this context [37]. Regarding skeletal health, Young et al., reported interactive effects of vitamin D and calcium on fetal skeletal development in pregnant adolescents [42] and negative synergistic effects of inadequate vitamin $\mathrm{D}$ and calcium have been described in rickets [43]. Calcium supplementation of pregnant Gambian women (vitamin D sufficient but with habitual calcium intakes of $\sim 350 \mathrm{mg} /$ day) did not impact offspring bone but had an unexpected detrimental effect on maternal bone [44,45]. Postulated by the authors to result from disruption of metabolic adaptation to habitual low intakes, this highlights the complexities of the calcium metabolic system. The vitamin D-calcium metabolic system may also impact other perinatal outcomes. Vitamin D and calcium have been investigated with regards to hypertensive disorders of pregnancy $[8,9,18]$ and functional vitamin D deficiency (low 25(OH)D plus elevated PTH), rather than low 25(OH)D alone, may adversely affect gestational blood pressure and preeclampsia [24,25]. Stress to the calcium metabolic system has also been associated with small-for-gestational-age birth [46], although we found an increased risk of small-for-gestational-age in those with functional vitamin D deficiency was attenuated with full confounder adjustment [24].

The strengths of this study include use of the gold standard method of CDC-accredited LC/MS-MS for measurement of 25(OH)D. Further, a complete dataset was available for $99 \%$ of original trial participants. We did not have intake or status data for other potentially relevant nutrients including phosphorus and magnesium, both of which may influence PTH and the calcium metabolic system $[47,48]$. Additionally, vitamin $\mathrm{K}$ plays a role in calcium homeostasis and bone health and synergistic effects of vitamin $\mathrm{D}$ and vitamin $\mathrm{K}$ have been reported [49,50]. A broader examination of the calcium metabolic system encompassing such nutrients would be of interest. The context of the study should be given due consideration when drawing conclusions. All participants were white, which is relevant given acknowledged differences in vitamin D and PTH between ethnic groups. Specifically, 25(OH)D and PTH concentrations [24], as well as the threshold relationship between 25(OH)D and PTH have been reported to differ depending on ethnicity [51,52]. Future studies should give careful consideration to participant ethnicity, with priority given to conducting studies among women of ethnic minority [53]. Also, because habitual calcium intakes may impact results, repetition of analysis in pregnant women with low habitual intakes is of interest. This is particularly pertinent given the high prevalence of inadequate calcium intakes worldwide [36] and potential metabolic adaptation to high/low habitual calcium intakes. A large study encompassing participants with a wide range of calcium intakes may be of particular benefit in this regard.

\section{Conclusions}

To conclude, in this group of healthy, white-skinned pregnant women at Northern latitude and with largely sufficient calcium intakes, serum $25(\mathrm{OH}) \mathrm{D}$ concentration, but not calcium intake, was important for maintaining PTH concentration.

Supplementary Materials: The following are available online at http:/ / www.mdpi.com/2072-6643/10/7/916/s1, Figure S1: Scatterplot of log parathyroid hormone and 25-hydroxyvitamin D in 142 pregnant women, Figure S2: Scatterplot of 25-hydroxyvitamin D and vitamin D intake in 142 pregnant women.

Author Contributions: A.H. and M.E.K. conceptualized and designed the research. M.E.K. and K.D.C. are grant-holders. K.M.O. and Á.H. conducted clinical visits. G.L.J.H., K.M.O. and A.H. conducted biochemical analysis. A.H. conducted statistical analysis. A.H. and M.E.K. wrote the manuscript and M.E.K. was responsible for the final content.

Funding: This study was supported by funding from the European Commission under grant agreement 613977 for the ODIN Integrated Project (Food-based solutions for optimal vitamin D nutrition and health throughout the life cycle, http://www.odin-vitd.eu/).

Acknowledgments: Sincere thanks to all participants of the study.

Conflicts of Interest: The authors declare no conflict of interest. 


\section{References}

1. Haider, B.A.; Bhutta, Z.A. Multiple-micronutrient supplementation for women during pregnancy. Cochrane Database Syst. Rev. 2017, 4, CD004905. [CrossRef] [PubMed]

2. Saraf, R.; Morton, S.M.; Camargo, C.A., Jr.; Grant, C.C. Global summary of maternal and newborn vitamin D status-A systematic review. Matern. Child Nutr. 2016, 12, 647-668. [CrossRef] [PubMed]

3. Vinkhuyzen, A.A.E.; Eyles, D.W.; Burne, T.H.; Blanken, L.M.E.; Kruithof, C.J.; Verhulst, F.; Jaddoe, V.W.; Tiemeier, H.; McGrath, J.J. Prevalence and predictors of vitamin D deficiency based on maternal mid-gestation and neonatal cord bloods: The generation R study. J. Steroid Biochem. Mol. Biol. 2016, 164, 161-167. [CrossRef] [PubMed]

4. Bärebring, L.; Schoenmakers, I.; Glantz, A.; Hulthén, L.; Jagner, A.; Ellis, J.; Bärebring, M.; Bullarbo, M.; Augustin, H. Vitamin D status during pregnancy in a multi-ethnic population-representative Swedish cohort. Nutrients 2016, 8, 655. [CrossRef] [PubMed]

5. Kiely, M.E.; Zhang, J.Y.; Kinsella, M.; Khashan, A.S.; Kenny, L.C. Vitamin D status is associated with uteroplacental dysfunction indicated by pre-eclampsia and small-for-gestational-age birth in a large prospective pregnancy cohort in Ireland with low vitamin D status. Am. J. Clin. Nutr. 2016, 104, 354-361. [CrossRef] [PubMed]

6. Kiely, M.; O’Donovan, S.M.; Kenny, L.C.; Hourihane, J.O.; Irvine, A.D.; Murray, D.M. Vitamin D metabolite concentrations in umbilical cord blood serum and associations with clinical characteristics in a large prospective mother-infant cohort in Ireland. J. Steroid Biochem. Mol. Biol. 2017, 167, 162-168. [CrossRef] [PubMed]

7. Haggarty, P.; Campbell, D.M.; Knox, S.; Horgan, G.W.; Hoad, G.; Boulton, E.; McNeill, G.; Wallace, A.M. Vitamin D in pregnancy at high latitude in Scotland. Br. J. Nutr. 2013, 109, 898-905. [CrossRef] [PubMed]

8. Roth, D.E.; Leung, M.; Mesfin, E.; Qamar, H.; Watterworth, J.; Papp, E. Vitamin D supplementation during pregnancy: State of the evidence from a systematic review of randomised trials. BMJ 2017, 359, j5237. [CrossRef] [PubMed]

9. De-Regil, L.M.; Palacios, C.; Lombardo, L.K.; Peña-Rosas, J.P. Vitamin D supplementation for women during pregnancy. Cochrane Database Syst. Rev. 2016, 1, CD008873.

10. Aghajafari, F.; Nagulesapillai, T.; Ronksley, P.E.; Tough, S.C.; O’Beirne, M.; Rabi, D.M. Association between maternal serum 25-hydroxyvitamin D level and pregnancy and neonatal outcomes: Systematic review and meta-analysis of observational studies. BMJ 2013, 346, f1169. [CrossRef] [PubMed]

11. Institute of Medicine. Dietary Reference Intakes for Calcium and Vitamin D; Ross, A.C., Taylor, C.L., Yaktine, A.L., Valle, H.B.D.V., Eds.; National Academies Press: Washington, DC, USA, 2011; pp. 35-345.

12. Nordic Council of Ministers. Nordic Nutrition Recommendations 2012, 5th ed.; Narayana Press: Copenhagen, Denmark, 2014.

13. European Food Safety Authority. Scientific opinion on dietary reference values for vitamin D. EFSA J. 2016, $14,4547$.

14. O'Callaghan, K.M.; Hennessy, Á.; Hull, G.L.; Healy, K.; Ritz, C.; Kenny, L.C.; Cashman, K.D.; Kiely, M.E. Estimation of the maternal vitamin D intake that maintains circulating 25-hydroxyvitamin $\mathrm{D}$ in late gestation at a concentration sufficient to keep umbilical cord sera $\geq 25-30 \mathrm{nmol} / \mathrm{L}$ : A dose-response, double-blind, randomized placebo-controlled trial in pregnant women at northern latitude. Am. J. Clin. Nutr. 2018, 108, 77-91. [PubMed]

15. March, K.M.; Chen, N.N.; Karakochuk, C.D.; Shand, A.W.; Innis, S.M.; von Dadelszen, P.; Barr, S.I.; Lyon, M.R.; Whiting, S.J.; Weiler, H.A.; et al. Maternal vitamin $\mathrm{D}_{3}$ supplementation at $50 \mu \mathrm{g} / \mathrm{d}$ protects against low serum 25-hydroxyvitamin D in infants at $8 \mathrm{wk}$ of age: A randomized controlled trial of 3 doses of vitamin D beginning in gestation and continued in lactation. Am. J. Clin. Nutr. 2015, 102, 402-410. [CrossRef] [PubMed]

16. Prentice, A. Mining the depths: Metabolic insights into mineral nutrition. Proc. Nutr. Soc. 2007, 66, 512-521. [CrossRef] [PubMed]

17. Redmond, J.; Jarjou, L.M.; Zhou, B.; Prentice, A.; Schoenmakers, I. Ethnic differences in calcium, phosphate and bone metabolism. Proc. Nutr. Soc. 2014, 73, 340-351. [CrossRef] [PubMed]

18. Hofmeyr, G.J.; Lawrie, T.A.; Atallah, A.N.; Duley, L.; Torloni, M.R. Calcium supplementation during pregnancy for preventing hypertensive disorders and related problems. Cochrane Database Syst. Rev. 2014, 6, CD001059. [CrossRef] [PubMed] 
19. Brannon, P.M.; Picciano, M.F. Vitamin D in pregnancy and lactation in humans. Annu. Rev. Nutr. 2011, 31, 89-115. [CrossRef] [PubMed]

20. Møller, U.K.; Streym, S.; Mosekilde, L.; Heickendorff, L.; Flyvbjerg, A.; Frystyk, J.; Jensen, L.T.; Rejnmark, L. Changes in calcitropic hormones, bone markers and insulin-like growth factor I (IGF-I) during pregnancy and postpartum: A controlled cohort study. Osteoporos Int. 2013, 24, 1307-1320. [CrossRef] [PubMed]

21. Hamilton, S.A.; McNeil, R.; Hollis, B.W.; Davis, D.J.; Winkler, J.; Cook, C.; Warner, G.; Bivens, B.; McShane, P.; Wagner, C.L. Profound vitamin D deficiency in a diverse group of women during pregnancy living in a sun-rich environment at latitude $32^{\circ} \mathrm{N}$. Int. J. Endocrinol. 2010, 917428. [CrossRef] [PubMed]

22. Prentice, A. Vitamin D deficiency: A global perspective. Nutr. Rev. 2008, 66, S153-S164. [CrossRef] [PubMed]

23. Lips, P. Vitamin D deficiency and secondary hyperparathyroidism in the elderly: Consequences for bone loss and fractures and therapeutic implications. Endocr. Rev. 2001, 22, 477-501. [CrossRef] [PubMed]

24. Hemmingway, A.; Kenny, L.C.; Malvisi, L.; Kiely, M.E. Exploring the concept of functional vitamin D deficiency in pregnancy: impact of the interaction between 25-hydroxyvitamin D and parathyroid hormone on perinatal outcomes. Am. J. Clin. Nutr 2018, in press.

25. Scholl, T.O.; Chen, X.; Stein, T.P. Vitamin D, secondary hyperparathyroidism, and preeclampsia. Am. J. Clin. Nutr. 2013, 98, 787-793. [CrossRef] [PubMed]

26. Cashman, K.D.; Hill, T.R.; Lucey, A.J.; Taylor, N.; Seamans, K.M.; Muldowney, S.; Fitzgerald, A.P.; Flynn, A.; Barnes, M.S.; Horigan, G.; et al. Estimation of the dietary requirement for vitamin D in healthy adults. Am. J. Clin. Nutr. 2008, 88, 1535-1542. [CrossRef] [PubMed]

27. Cashman, K.D.; Wallace, J.M.; Horigan, G.; Hill, T.R.; Barnes, M.S.; Lucey, A.J.; Bonham, M.P.; Taylor, N.; Duffy, E.M.; Seamans, K.; et al. Estimation of the dietary requirement for vitamin D in free-living adults $\geq 64$ y of age. Am. J. Clin. Nutr. 2009, 89, 1366-1374. [CrossRef] [PubMed]

28. Mortensen, C.; Damsgaard, C.T.; Hauger, H.; Ritz, C.; Lanham-New, S.A.; Smith, T.J.; Hennessy, Á.; Dowling, K.; Cashman, K.D.; Kiely, M.; et al. Estimation of the dietary requirement for vitamin D in white children aged 4-8 y: A randomized, controlled, dose-response trial. Am. J. Clin. Nutr. 2016, 104, 1310-1317. [CrossRef] [PubMed]

29. Smith, T.J.; Tripkovic, L.; Damsgaard, C.T.; Molgaard, C.; Ritz, C.; Wilson-Barnes, S.L.; Dowling, K.G.; Hennessy, Á.; Cashman, K.D.; Kiely, M.; et al. Estimation of the dietary requirement for vitamin D in adolescents aged 14-18 y: A dose-response, double-blind, randomized placebo-controlled trial. Am. J. Clin. Nutr. 2016, 104, 1301-1309. [CrossRef] [PubMed]

30. Kiely, M.; Collins, A.; Lucey, A.J.; Andersen, R.; Cashman, K.D.; Hennessy, Á. Development, validation and implementation of a quantitative food frequency questionnaire to assess habitual vitamin D intake. J. Hum. Nutr. Diet. 2016, 29, 495-504. [CrossRef] [PubMed]

31. Goltzman, D. Approach to Hypercalcemia; de Groot, L.J., Chrousos, G., Dungan, K., Eds.; Endotext: South Dartmouth, MA, USA, 2016.

32. Holick, M.F.; Binkley, N.C.; Bischoff-Ferrari, H.A.; Gordon, C.M.; Hanley, D.A.; Heaney, R.P.; Murad, M.H.; Weaver, C.M.; Endocrine Society. Evaluation, treatment, and prevention of vitamin D deficiency: An Endocrine Society clinical practice guideline. J. Clin. Endocrinol. Metab. 2011, 96, 1911-1930. [CrossRef] [PubMed]

33. Black, L.J.; Walton, J.; Flynn, A.; Cashman, K.D.; Kiely, M. Small increments in vitamin D intake by Irish adults over a decade show that strategic initiatives to fortify the food supply are needed. J. Nutr. 2015, 145, 969-976. [CrossRef] [PubMed]

34. Irish University Nutrition Alliance. National Adult Nutrition Survey: Summary Report, 2011. National Food Consumption Surveys in Ireland. 2011. Available online: https:/ / www.iuna.net/surveyreports (accessed on 1 June 2018).

35. Joy, E.J.; Ander, E.L.; Young, S.D.; Black, C.R.; Watts, M.J.; Chilimba, A.D.; Chilima, B.; Siyame, E.W.; Kalimbira, A.A.; Hurst, R.; et al. Dietary mineral supplies in Africa. Physiol. Plant 2014, 151, $208-229$. [CrossRef] [PubMed]

36. Kumssa, D.B.; Joy, E.J.; Ander, E.L.; Watts, M.J.; Young, S.D.; Walker, S.; Broadley, M.R. Dietary calcium and zinc deficiency risks are decreasing but remain prevalent. Sci. Rep. 2015, 5, 10974. [CrossRef] [PubMed]

37. Kiely, M.; Hemmingway, A.; O'Callaghan, K.M. Vitamin D in pregnancy: current perspectives and future directions. Ther. Adv. Musculoskelet. Dis. 2017, 9, 145-154. [CrossRef] [PubMed] 
38. Jorde, R.; Sundsfjord, J.; Haug, E.; Bonaa, K.H. Relation between low calcium intake, parathyroid hormone, and blood pressure. Hypertension 2000, 35, 1154-1159. [CrossRef] [PubMed]

39. Steingrimsdottir, L.; Gunnarsson, O.; Indridason, O.S.; Franzson, L.; Sigurdsson, G. Relationship between serum parathyroid hormone levels, vitamin D sufficiency, and calcium intake. JAMA 2005, 294, 2336-2341. [CrossRef] [PubMed]

40. Joo, N.S.; Dawson-Hughes, B.; Kim, Y.S.; Oh, K.; Yeum, K.J. Impact of calcium and vitamin D insufficiencies on serum parathyroid hormone and bone mineral density: Analysis of the fourth and fifth Korea national health and nutrition examination survey. J. Bone Miner. Res. 2013, 28, 764-770. [CrossRef] [PubMed]

41. Cashman, K.D.; Hayes, A.; O’Donovan, S.M.; Zhang, J.Y.; Kinsella, M.; Galvin, K.; Kiely, M.; Seamans, K.M. Dietary calcium does not interact with vitamin $\mathrm{D}_{3}$ in terms of determining the response and catabolism of serum 25-hydroxyvitamin D during winter in older adults. Am. J. Clin. Nutr. 2014, 99, 1414-1423. [CrossRef] [PubMed]

42. Young, B.E.; McNanley, T.J.; Cooper, E.M.; McIntyre, A.W.; Witter, F.; Harris, Z.L.; O’Brien, K.O. Maternal vitamin D status and calcium intake interact to affect fetal skeletal growth in utero in pregnant adolescents. Am. J. Clin. Nutr. 2012, 95, 1103-1112. [CrossRef] [PubMed]

43. Pettifor, J.M. Calcium and vitamin D metabolism in children in developing countries. Ann. Nutr. Metab. 2014, 64 (Suppl. 2), 15-22. [CrossRef] [PubMed]

44. Jarjou, L.M.A.; Prentice, A.; Sawo, Y.; Laskey, M.A.; Bennett, J.; Goldberg, G.R.; Cole, T.J. Randomized, placebo-controlled, calcium supplementation study in pregnant Gambian women: Effects on breast-milk calcium concentrations and infant birth weight, growth, and bone mineral accretion in the first year of life. Am. J. Clin. Nutr. 2006, 83, 657-666. [CrossRef] [PubMed]

45. Jarjou, L.M.; Laskey, M.A.; Sawo, Y.; Goldberg, G.R.; Cole, T.J.; Prentice, A. Effect of calcium supplementation in pregnancy on maternal bone outcomes in women with a low calcium intake. Am. J. Clin. Nutr. 2010, 92, 450-457. [CrossRef] [PubMed]

46. Scholl, T.O.; Chen, X.; Stein, T.P. Maternal calcium metabolic stress and fetal growth. Am. J. Clin. Nutr. 2014, 99, 918-925. [CrossRef] [PubMed]

47. Calvo, M.S.; Uribarri, J. Public health impact of dietary phosphorus excess on bone and cardiovascular health in the general population. Am. J. Clin. Nutr. 2013, 98, 6-15. [CrossRef] [PubMed]

48. Castiglioni, S.; Cazzaniga, A.; Albisetti, W.; Maier, J.A. Magnesium and osteoporosis: Current state of knowledge and future research directions. Nutrients 2013, 5, 3022-3033. [CrossRef] [PubMed]

49. Ahmadieh, H.; Arabi, A. Vitamins and bone health: Beyond calcium and vitamin D. Nutr. Rev. 2011, 69, 584-598. [CrossRef] [PubMed]

50. Gröber, U.; Reichrath, J.; Holick, M.F.; Kisters, K. Vitamin K: An old vitamin in a new perspective. Dermatoendocrinol. 2014, 6, e968490. [CrossRef] [PubMed]

51. Gutiérrez, O.M.; Farwell, W.R.; Kermah, D.; Taylor, E.N. Racial differences in the relationship between vitamin $\mathrm{D}$, bone mineral density, and parathyroid hormone in the National Health and Nutrition Examination Survey. Osteoporos. Int. 2011, 22, 1745-1753. [CrossRef] [PubMed]

52. Aloia, J.F.; Chen, D.G.; Chen, H. The 25(OH)D/PTH threshold in black women. J. Clin. Endocrinol. Metab. 2010, 95, 5069-5073. [CrossRef] [PubMed]

53. O'Callaghan, K.M.; Kiely, M.E. Ethnic disparities in the dietary requirement for vitamin D during pregnancy: Considerations for nutrition policy and research. Proc. Nutr. Soc. 2018, 77, 164-173. [CrossRef] [PubMed]

(C) 2018 by the authors. Licensee MDPI, Basel, Switzerland. This article is an open access article distributed under the terms and conditions of the Creative Commons Attribution (CC BY) license (http://creativecommons.org/licenses/by/4.0/). 